\title{
A new manifestation of thrombocytopenia: myocardial haemorrhage with symptomatic arrhythmia
}

\author{
PJ WYLD, S BECK, * DN SLATER* \\ From the Department of Haematology and *Histopathology, Royal Hallamshire Hospital, Sheffield
}

SUMMARY We describe a patient with thrombocytopenia who developed episodes of dyspnoea due to recurrent cardiac arrhythmia. Necropsy revealed that the apparent mechanism was extensive myocardial haemorrhage.

Complications of thrombocytopenia, such as cutaneous bruising, intracerebral and gastrointestinal haemorrhage are well recognised. Subendocardial and pericardial haemorrhage is a frequent necropsy finding in thrombocytopenic patients. However, the findings are generally considered to be of no clinical significance. We describe a patient with thrombocytopenia who developed breathless attacks for several weeks before death. Twenty-four hour electrocardiograph recordings showed intermittent cardiac arrhythmias and necropsy demonstrated the apparent mechanism was myocardial haemorrhage.

\section{Case report}

In 1971, a 49-year-old woman was found to have essential thrombocythaemia and was treated with ${ }^{32} \mathrm{P}$ (total dose $33 \mathrm{mCi}$ ).

She presented again in May 1980 with tiredness and easy bruising. Investigations showed a haemoglobin concentration of $11 \mathrm{~g} / \mathrm{dl}$ and a platelet count of $10 \times 10^{9} / 1$. Bone marrow examination revealed myelofibrosis with an increase in blast cells. Some remission in her symptoms was achieved by treatment with vincristine and prednisolone. However, she remained severely thrombocytopenic with skin purpura and episodes of epistaxis and she required platelet transfusion. She was transfused a total of 20 single donor units of platelets.

In August 1980, she developed recurrent transient episodes of dyspnoea lasting for up to several minutes. There were at first irregular occurring no more than twice weekly but subsequently became more troublesome, increasing in frequency to several times daily. Examination during an attack showed tachycardia (apical rate $120-150 / \mathrm{min}$ ) but

Accepted for publication 4 January 1982 no evidence of clinically detectable pulmonary oedema. A continuous twenty-four hour electrocardiograph revealed that the dyspnoea was associated with sinus tachycardia; this was followed by gradual slowing and the development of an atrioventricular (AV) junctional (nodal) escape rhythm with the occasional ventricular extrasystole. Plasma sodium, potassium, calcium and magnesium, serum thyroxin and acid base balance were normal. The cause of the arrhythmia was uncertain and the episodes of dyspnoea continued up to the time of her death in September 1980. The attacks were not related to platelet transfusions and the patient was not taking drugs.

\section{NECROPSY}

Necropsy demonstrated that the immediate cause of death was a massive gastrointestinal haemorrhage associated with numerous petechiae in the gastric mucosa. There were also scattered petechiae in the skin, brain, and renal pelvis.

The heart macroscopically (Fig. 1) showed numerous haemorrhages on the epi- and endocardial surfaces of the right atrium, right atrial appendage and at the base of the interatrial septum. The conducting system was dissected using the method described by Davies ${ }^{2}$ and histological examination showed severe widespread haemorrhage into the myocardium of the right atrium with distortion and separation of the muscle fibres (Fig. 2). Haemosiderin-laden macrophages indicated that previous haemorrhagic episodes had occurred. Haemorrhage was also present around the nerve fibres of the subpericardial plexus and in the fibrous ring adjacent to the AV nodal artery. The sinoatrial (SA) artery, muscle fibres of the SA and AV nodes and bundle of His were normal. 


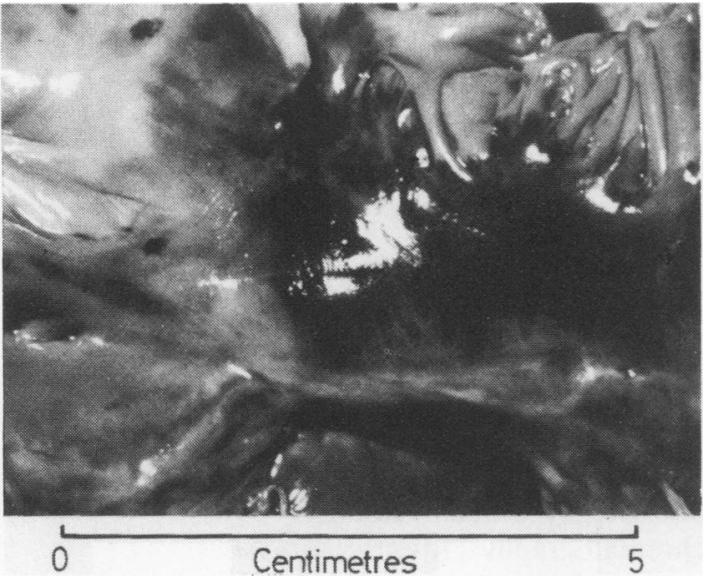

Fig. 1 Right atrial haemorrhage above the tricuspid valve.

The left atrial muscle and ventricular myocardium were largely devoid of haemorrhage. All coronary arteries showed less than $5 \%$ luminal occlusion by atheroma and the lungs were histologically normal.

\section{Discussion}

The terminal phase of our patient's disease was characterised by thrombocytopenia. She was transfusion-dependent and showed intermittent cutaneous haemorrhagic signs. The troublesome transient episodes of dyspnoea were difficult to understand and it was not until the twenty-four hour electrocardiograph was performed that a relation was shown between the dyspnoea and an arrhythmia.

Myocardial haemorrhage due to operative trauma in patients undergoing cardiac surgery is recognised to be as a cause of atrial arrhythmia ${ }^{3}$ and complete heart block. ${ }^{4}$ Arrhythmias have also been associated with haemorrhage in a patient with diphtheria ${ }^{5}$ and it is interesting that Menzies states that traumatic myocardial contusion is consistently associated with a tachycardia. ${ }^{6}$

Necropsy studies of patients dying from leukaemia have demonstrated the presence of both petechial haemorrhages and cellular infiltrates in the conducting system. ${ }^{7}$ Although the occasional report has shown a relation between leukaemic infiltration and a cardiac arrhythmia ${ }^{8}$ myocardial haemorrhage has not been previously reported as a cause of arrhythmia in a leukaemic or thrombocytopenic patient.

It is possible that this complication of thrombocytopenia occurs not infrequently and Dresdale

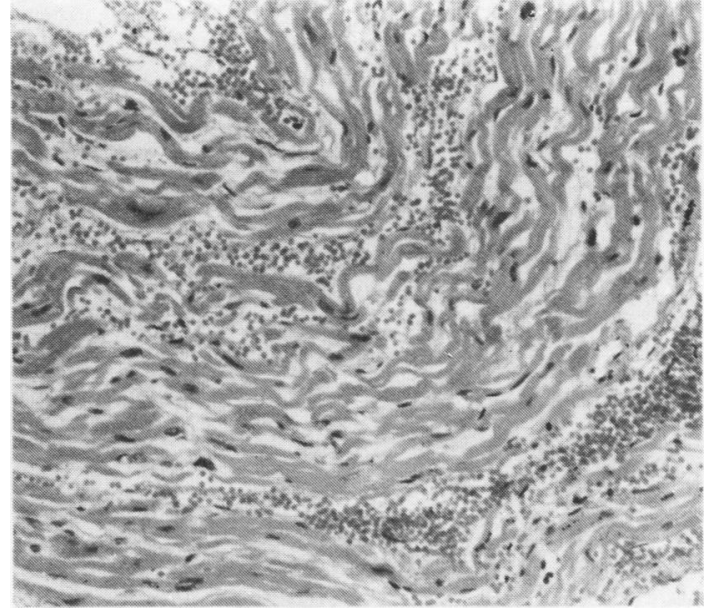

Fig. 2 Extensive right atrial haemorrhage causing separation and distortion of the myocardial fibres. Haematoxylin and eosin $\times 295$.

et $a^{9}$ suggested that, without specific electrocardiological investigations, various arrhythmias in haematological patients may be overlooked due to a coexistent tachycardia associated with anaemia and pyrexia.

In the absence of any other predisposing factor, it appears probable that the cause of the AV junctional rhythm in our patient was an escape rhythm after disruption of the normal conducting pathways between the SA and AV node.

We are grateful to Professor EK Blackburn for permission to report this case and to Dr J Fleming for interpretation of the 24-hour electrocardiogram.

\section{References}

' Kirshbaum JD, Preuss FS. Leukaemia: clinical and pathologic study of 123 fatal cases in a series of 14400 necropsies. Arch Intern Med 1943;71:777-92.

${ }^{2}$ Davies MJ. Pathology of conductive tissue of the heart. London: Butterworths, 1971:29-37.

${ }^{3}$ Tung KSK, James TN, Effler DB, McCormack LJ. Injury of the sinus node in open-heart operations. J Thorac Cardiovasc Surg 1968;53:814-26.

${ }^{4}$ Hudson REB. Surgical pathology of the conducting system of the heart. Br Heart J 1967;29:646-70.

5 James TN, Reynolds EW. Pathology of the cardiac conducting system in case of diphtheria associated with atrial arrhythmias and heart block. Circulation 1963;28:263-7.

- Menzies RC. Cardiac contusion: a review. Med Sci Law 1978;18:3-12.

' Roberts WC, Bodey GP, Wertlake PT. The heart in acute leukaemia. A study of 420 autopsy cases. Am J Cardiol 1968;21:388-412.

${ }^{8}$ Mahaim I, Rossier PH. Leucémie myéloide aigue, diathèse hémorragique, bloc auriculo-ventriculaire. Lésions du tissue spécifique. Cardiologica 1949;15:196-208. 
${ }^{9}$ Dresdale DT, Spain D, Perez-Pine F. Heart block and leukaemic cell infiltration of interventricular septum of heart. Am J Med 1949;6:530-3.
Requests for reprints to: Dr DN Slater, Department of Pathology, Medical School, Beech Hill Road, Sheffield S10 2RX, England.

\section{The July 1982 issue}

\section{THE JULY 1982 ISSUE CONTAINS THE FOLLOWING PAPERS}

Hepatitis B and A virus antibodies in alcoholic steatosis and cirrhosis C GLUUD, J ALDERSHVILE, J HENRIKSEN, P KRYGER, L MATHIESEN

Problems in the disinfection of class 1 microbiology safety cabinets PH EVERALL, CA MORRIS, PR OLIVER, JF BECKER

Can direct gas-liquid chromatography of clinical samples detect specific organisms? B WATT, PAMELA A GEDDES, OLGA A GREENAN, SUSAN K NAPIER, A MITCHELL

Gas-liquid chromatography in the diagnosis of anaerobic infections: a three year experience B WATT, PAMELA A GEDDES, OLGA A GREENAN, SUSAN K NAPIER, A MITCHELL

Diagnosis of bacteraemia by automated head-space capillary gas chromatography L LARSSON, P-A MÅRDH, G ODHAM, M-L CARLSSON

Evaluation of an improved Streptex kit for the grouping of beta-haemolytic streptococci by agglutination D CASTLE, S KESSOCK-PHILIP, CSF EASMON

Fibronectin in exudative pleural effusions MATTI KLOCKARS, T PETTERSSON, T VARTIO, H RISKA, A VAHERI

Effect of treatment with $17 \alpha$-alkylated androgens on $\mathrm{C} 4$ conversion products in hereditary angioedema studies by crossed immunoelectrophoresis L BERGAMASCHINI, M CICARDI, ANTONIETTA TUCCI, A AGOSTONI

Hypercalcaemia due to the co-existence of parathyroid adenoma and myelomatosis RM FRANCIS, AG BYNOE, C GRAY

Glycosylated haemoglobin in chronic renal failure and after renal transplantation D FREEDMAN, P DANDONA, O FERNANDO, JF MOORHEAD

Platelet inhibition with Ticlopidine in atherosclerotic intermittent claudication A AUKLAND, RA HURLOW, AJ GEORGE, J STUART
Occurrence of infection with a parvovirus-like agent in children with sickle cell anaemia during a two-year period MJ ANDERSON, LR DAVIS, J HODGSON, SE JONES, L MURTAZA, JR PATTISON, CE STROUD, JM WHITE

Reaction against liver cells by human antiactin antibodies purified by affinity chromatography KIRSTEN RIISOM, H DIEDERICHSEN, INGER ANDERSEN

Influence of the gallbladder on serum bile acids CR PENNINGTON, PE ROSS, IAD BOUCHIER

Five year follow-up study of gastritis MC ORMISTON, MWL GEAR, BW CODLING

Comparison of the Trucut and Surecut liver biopsy needles ER LITTLEWOOD, IT GILMORE, IM MURRAY-LYON, KR STEPHENS, FJ PARADINAS

Somatostatin: a paracrine contribution to hypothyroidism in Hashimoto's thyroiditis AP DHILLON, J RODE, A LEATHEM, LUCIENNE PAPADAKI

Ultrastructural features of the osteoclasts from Paget's disease of bone in relation to a viral aetiology L HARVEY, T GRAY, MNC BENETON, DL DOUGLAS, JA KANIS, RGG RUSSELL

Adamantinoma of long bones: clinical, pathological and ultrastructural features AS PIETERSE, PS SMITH, J McCLURE

Technical methods

Assay of $\beta$-lactam antibiotics when used therapeutically in combination with aminoglycosides BH POSTMA

Congo blue: a rapid stain for elastic fibres JD DAVIES, EW YOUNG

\section{Letters to the Editor}

Book reviews

Notices

Some new titles

Copies are still available and may be obtained from the PUBLISHING MANAGER, 